\title{
FLIPPED CLASSROOM IN EFL READING CLASS (An Experimental Study)
}

\author{
Rini Oktiyani ${ }^{1}$, Nunun Indrasari ${ }^{2}$, Rahmi Isnaini ${ }^{3}$ \\ SDN 1 Way Dadi ${ }^{1}$, UIN Raden Intan Lampung ${ }^{2}$, Universitas Lampung ${ }^{3}$ \\ rahmiisnaini@gmail.com
}

\begin{abstract}
This research aims to know whether there is an influence of Flipped classroom towards students' Reading Comprehension on Narrative Text at the Second Semester of Eighth Grade at SMPN 1 Marga Sekampung in Academic Year of 2018/2019. The research design was quasi experimental design with the treatment held in three meetings, $2 \times 40$ minutes in each meeting. The samples of this research were two classes, VIII $C$ as the experimental class and VIII $B$ as the control class. The researcher used Flipped classroom in experimental class and Traditional Classroom as the model by the English teacher in control class. The experimental class consisted of 31 students and control class consisted of 32 students. In collecting data, the researcher used test instruments of pre-test and post-test. The researcher used Independent Sample T-Test to analyze those data. The result showed that $t_{\text {observed }}(2.5762)$ and $t_{\text {critical }}$ (1.9996), it means that $H_{a}$ is accepted and $H_{o}$ is rejected. It can be concluded that there is a significant influence of using Flipped classroom towards students' reading comprehension in Narrative Text.
\end{abstract}

Keywords: Flipped Classroom, Narrative Text, Quasi Experimental, Reading Comprehension. 


\section{A. INTRODUCTION}

There is no doubt that reading has played an important role in learning English. Reading provides many benefits in increasing students' knowledge and train the brain to actively think. Reading is the process of comprehending written material in order to obtain information. Additionally, it serves as a means of communication between reader and author. The text can serve as a conduit for readers to learn the information that the researcher wishes to convey. For that, readers should have expertise to understand it. Especially, the learners should possess reading ability because it will be useful when they read.

Moreover, reading is said to be an example of how discrete language ability can affect a student's academic progress, since formal reading instruction is usually not sufficient to create a reader. Independent reading, or practice, must also be present in order for a student to become a good reader. It means reading requires awareness to build habit of reading. Even though reading is important in increasing language ability, it still needs instruction to push students to read. It would be better if teacher can persuade or make them interested in the material. If students want to be a good reader, there should be a strong desire to know something new from a text or book. Furthermore, in teaching, the teachers need to be able to motivate the students to read more rather than just give instruction in reading activities.

Based on interviewing an English teacher and some students at the eighth grade of SMPN 1 Marga Sekampung East Lampung, the researcher found that the students 
had difficulties in learning English. The students can pronounce the words but they do not really understand what the meaning of the sentence because they lack of vocabulary. They only translate the difficult words one by one using the dictionary. It was not effective because it spent a lot of time. They also have difficulty in interpreting whole text especially in narrative text. Then, it makes them lazy to read a long text. The problem arises when the teacher only uses one model class. It is traditional classroom which requires students to translate word by word using a dictionary in the classroom. The low comprehension of the students was also proven with their score in reading in which $61,70 \%$ students got score under criteria of minimum standard (KKM).

Therefore, to solve those problems, the researcher decided to choose one model classroom called flipped classroom. In this research, the researcher used Flipped classroom in teaching reading. Bergman and Sams state that Flipped Classroom is a discussion about the materials from the night before classes, in which, what is traditionally done in class is now done at home. In this research, the researcher used some videos for teaching media. It is a way when the students should learn materials at home before attending the class. In class the teacher can focus on the exercises and discuss what they do not understand on video's material.

In addition, the four Pillars of F-L-I-P are Flexible Environment, Learning Culture, Intentional Content, and Professional Educator. Flexible environment means that learners can choose whenever and wherever they want to study. Learning Culture 
means that it helps learners to explore topics deeply by using their level ability. Then, it's important to the teacher to choose the material that is appropriate for their students. Intentional Content means that the teacher must evaluate and decides what they need to discuss or not in the material. The last professional educator means that teachers have to do their role as facilitators effectively and become a good role model to their students. In short, flipped classroom gives students more chance in learning process outside the class and can helps students comprehend more about reading texts because the time is more flexible.

To support this research, the researcher takes review of related article from other researchers. The research arranged by Abaeian and Samadi, on the Effect of Flipped Classroom on Iranian EFL learners' L2 Reading Comprehension: Focusing on Different Proficiency Levels. They conduct the data by using t-tests to compare results between the experimental group and control group. The participants were 100 female EFL learners with different proficiency levels, upper-intermediate and intermediate level learners. The result of their research showed that the intermediate learners benefit more than upper intermediate learners.

Karimi and Hamzavi conducted another research, the title is The Effect of Flipped Model of Instruction on EFL Learners' Reading Comprehension: Learners' Attitudes in Focus. They instruments used to collect the data in this research were test and questionnaire. They found that the students' attitudes in reading was still low. The result showed that teaching students by flipped classroom had a significant 
positive effect on reading comprehension ability and positive attitude towards flipped instruction.

Based on the previous researches above, there are some differences between this research and those researches. The first previous research used flipped classroom to compare flipped classroom effect on students' proficiency levels, upperintermediate and intermediate level learners in reading. Then, the second previous research used flipped classroom focusing on students' attitudes or students' habit in reading. Whether students can become independent readers or not. Meanwhile, in this research, researcher used flipped classroom to know the effect towards students' comprehension especially narrative text at the eighth grades student.

Based on the background of the problem above, the researcher concerned to identify “The Influence of Using Flipped classroom towards Students' Reading Comprehension on Narrative Text at Second Semester of Eighth Grade at SMPN 1 Marga Sekampung East Lampung in the Academic Year of 2018/2019" with the objective: to know the influence of using flipped classroom towards students' reading comprehension on narrative text.

\section{a. Reading Comprehension of Narrative Text}

Reading is primarily a perceptual and cognitive process, and research on reading focuses on the individual and what happens inside his or her head while reading (Mcintyre, 2011). It means that reading is process of constructing meaning from the content of the text by activating our brain. In addition, understanding the content of 
texts requires cognitive process to digest the meaning that the authors want to convey in written work. Every student has his/her own level in understanding English text. It can be seen from their ability to answer the questions related to the text or retell the contents of the text. Brown said in his book about some aspects in reading comprehension. They are; main idea (topic), expressions/idiom/phrases in context, inference (implied detail), grammatical features, detail (scanning for a specifically stated detail), excluding fact not written (unstated details), supporting idea, vocabulary in the context. From the theories above, the researcher can conclude that reading comprehension is an ability of comprehend about the text to get the information or knowledge.

Narrative text is the recounting of a series of events and establishing some (causal/temporal) relation between them. In narrative text, there are events in a time sequence, in which the characters in the story interact in various conflicts that is occured. There are three elements that must be in narrative text; events, emergence of characters, and conflict or problem that must be related to each other. It starts from introduction of problem in a story and there is a solution at the end.

Moreover, Knapp and Watkins wrote about function of Narrative text. They state that it has a powerful social role beyond that of being a medium for entertainment. It is also a powerful medium for changing social opinions and attitudes. It means narrative is to entertain the reader and give moral view or moral lesson. Authors usually put positive messages at the end of story. It's expected to make an 
impression for readers. Thus, narrative can be regarded as a collection of events that have problems until it becomes a story to entertain and give moral value to the reader.

Narratives include different types, or genres, that can vary somewhat from this basic story grammar template. These include realistic fiction, fantasy, fairytales, folktales, mysteries, humor, historical fiction, plays, real-life adventures and fables. In this research, the researcher decided to focus on fable text because fable is one type of narrative text that is available on the syllabus of second semester of eighth grade students at SMPN 1 Marga Sekampung. It is also compatible with students' need since students have difficulty on fable.

In conclusion, students' reading comprehension on narrative text is the ability of students in comprehending the text about story which has sequences of event and problems that aimed to entertain the readers with the aspects of main idea, inference (implied detail), grammatical features, detail, excluding fact/not written, supporting idea, and vocabulary in content.

\section{b. Flipped Classroom}

There are some concepts of flipped classroom defined by experts. Bergman and Sams state that flipped is a class model that uses a video to be a reading material at home that will be applied in class in the morning. Before teaching the students at class, teachers have to provide media or materials such as video that should be given to the students. At class, the video will be discussed together. If there is any 
misconception in the content, the student can ask the teacher. In other word, it is like homework for students before attending the class. The goal of this model is to optimize time allocation at class. Students are not just receiving the information from the teacher but they can learn it by themselves at home first. Thus, flipped classroom is said as the right way of previewing text to check students' understanding.

Additionally, Fuentes in Brunner states that flipped is a model intended to assist students in determining their own level of interest and prior knowledge about the topic prior to reading the selection. It means students pursue that model to assess their interested in the reading material. First, the students are given a question about the topic in the reading material. Then, they will try to find the answer about the topic. Next is the process of attracting the attention or interest of the students. If they are curious, it will be easier for teachers to direct students to choose the reading materials. In short, it keeps students close to reading and assesses their interest for certain topic of reading.

In addition, Drake states that flipped classroom model is heavily dependent on technology; students must have access to a computer (or similar device) and the internet so they can watch videos at home. Using technology and video to teaching learning process is highly recommended in this model. Then, it is very important to teacher to choose the material that is appropriate with their students. The video must be good, interesting, and catching the material clearly. In conclusion, Flipped 
classroom is a class model to help the students comprehend the text by using video before students read the text at class to get better comprehension of reading material.

\section{B. RESEARCH METHOD}

This research used quantitative based on experimental method. In this research, the researcher selected two classes. The first is a experimental class and the second is a control class. The experimental class is the class which get treatments by using Flipped classroom. Meanwhile, control class is taught by using a model that is usually used by teacher. In this research, the treatments were given three times either in experimental class or in control class. The population of this research is all students of eight grade of SMPN 1 Marga Sekampung in Academic year of 2018/2019 which consist of 3 classes. The samples of the research were two classes out of three classes at the eighth grade which were determined by using cluster random sampling technique. The total numbers of the sample were 63 students, 31 as experimental class and 32 as control class. The data was collected by using instrument of the test, pretest and posttest. Each test consisted of 25 items with multiple choice format and 4 options (A,B,C,D). The tests were constructed based on 8 aspects of reading comprehension, those are of main idea, expressions/idiom/ phrases in context, inference (implied detail), grammatical features, detail, excluding fact/not written, supporting idea, and vocabulary in content. 


\section{FINDINGS AND DISCUSSION}

In this research, the researcher gave tests before and after the treatments. After conducting pretest and posttest, the researcher got the students' score in experimental class and control class. The statistics of students' score in Experimental class can be seen in table 1. The table shows that the average of students' post-test score in the experimental class is 70.45 , median score is 72 , the smallest score is 52 , and the highest score is 88 . It can be concluded that the mean score of the students in posttest was higher than in pretest. The minimum and maximum score in posttest were also higher than in pretest.

\section{Table 1}

Statistics of the Result of Test in Experimental Class

\begin{tabular}{|l|c|c|}
\hline \multicolumn{1}{|c|}{ Statistics } & Pre-test & Post-test \\
\hline Mean & 63.87 & 70.45 \\
\hline Minimum & 48 & 52 \\
\hline Maximum & 80 & 88 \\
\hline Median & 64 & 72 \\
\hline
\end{tabular}

The table below shows the statistics of the result of pretest and posttest in control class. The average of students' post-test score in the control class is 66.94 , median

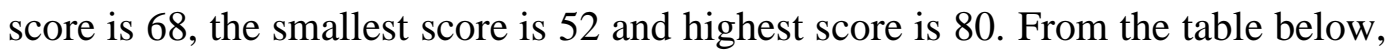


it can be concluded that the mean of students' score in posttest was higher than in pretest. The minimum and maximum score in posttest were also higher than in pretest.

Table 2

Statistics of the Result of Tests in Control Class

\begin{tabular}{|c|c|c|}
\hline Statistics & Pre-test & Post-test \\
\hline Mean & 64.63 & 66.94 \\
\hline Minimum & 48 & 52 \\
\hline Maximum & 80 & 80 \\
\hline Median & 64 & 68 \\
\hline
\end{tabular}

Before analyzing the data using a t-test, the researcher conducted a prerequisite test to determine whether the data was normal and homogenous. The result of normality test by using liliefors showed that the data was normal with $\mathrm{L}_{\text {observed }} 0.150$ in experimental class and 0.120 in control class. The result of homogeneity test showed that $F_{\text {observed }}$ is 1.027 and $F_{\text {critical }}$ is 1.83 . Therefore, it can be concluded that the data of control and experimental class are homogeneous because the score of $F_{\text {observed }}<F_{\text {critical. }}$ 
After getting the data of normality and homogeneity, the researcher used independent $\mathrm{t}$-test for hypothetical test. The result of independent $\mathrm{t}$-test can be seen in table 3.

Table 3

The Result of Independent T-Test

\begin{tabular}{|c|c|c|}
\hline \multicolumn{3}{|c|}{ t-Test: Two-Sample Assuming Equal Variances } \\
\hline & Experimental Class & Control Class \\
\hline Mean & 70.4516129 & 64.625 \\
\hline Variance & 70.85591398 & 89.91935484 \\
\hline Observations & 31 & 32 \\
\hline Pooled Variance & 80.54389212 & \\
\hline Hypothesized Mean Difference & 0 & \\
\hline Df & 61 & \\
\hline t Stat & 2.576234676 & Tᄀobserved \\
\hline $\mathrm{P}(\mathrm{T}<=\mathrm{t})$ one-tail & 0.006212599 & \\
\hline t Critical one-tail & 1.670219484 & \\
\hline $\mathrm{P}(\mathrm{T}<=\mathrm{t})$ two-tail & 0.012425198 & \\
\hline t Critical two-tail & 1.999623585 & Eritical \\
\hline
\end{tabular}


Based on the result obtained in the table 1 above, it is clear that value of significant generated Sig. ( $\mathrm{p}_{\text {value }}$ ) or Sig.(2-tailed) of the equal variance assumed $=0.006$ and 0.012 , and $\alpha=0.05$. It means that $\operatorname{Sig}$. $\left(\mathrm{p}_{\text {value }}<\alpha=0.05\right.$ and $\mathrm{T}_{\text {observed }}(2.57)>\mathrm{T}_{\text {critical }}$ (1.99). Therefore, $\mathrm{H}_{0}$ is rejected and $\mathrm{H}_{\mathrm{a}}$ is accepted. Based on the computation, it can be concluded that there was significant influence of using Flipped classroom towards students' reading comprehension at the second semester of the eighth grade of SMPN 1 Marga Sekampung East Lampung in the Academic Year of 2018/2019. After conducting the research, it is proven that there is significant influence of using Flipped classroom towards students' reading comprehension especially narrative text. It was proven by the result of the students' test score. The result showed that the experimental class's post-test score is higher than students' post-test score in the control class. It was the same with the result of previous research by Karimi and Hamzavi that showed flipped model of instruction had a significant positive effect on reading comprehension ability of EFL students.

This finding is also supported by Fuentes in Brunner, who states that flipped instruction is a model intended to assist students in assessing their own interest and prior knowledge about a subject prior to reading the selection. This means that it is appropriate to develop their comprehension of the text through pre-class video viewing.

The data analysis showed that the use of Flipped classroom in teaching reading comprehension encourages the students to be more active in teaching and learning 
reading comprehension on narrative text at the eighth grade of SMPN 1 Marga Sekampung East Lampung in academic years 2018/2019.

\section{CONCLUSION}

Flipped classroom benefits the students in the aspects of comprehending the text in more flexible time before attending the class. Students can have more time in understanding the meaning of whole story in narrative text. They can build more vocabulary by guessing the meaning of words while watching the scenes on the video. The students were more confident and more ready in reading class because they had already watched the video related to reading materials. So, flipped classroom can be one of alternative class models implemented by teachers in teaching reading as a new experience in learning. 


\section{E. REFERENCES}

Abaeian, Hamideh, and Samadi, Linda. 2016. "The Effect of Flipped

Classroom on Iranian EFL learners' L2 Reading Comprehension:

Focusing on Different Proficiency Levels”. Jurnal Education, Vol.

3 No. 6, P. 1

Bergmann, Jonathan, and Sams, Aaron. 2012. Flip Your Classroom

(Reach Every Student in Every Student in Every Class Every Day).

(Washington DC: Eugene Oregon) P. 13

Brunner, Judy Tilton. 2012. Now I Get It. (New York: R\&L Education),

$$
\text { P. } 79
$$

Drake, Lynne, Kayser, Micaela, and Jacobowitz, Robin. 2016. The Flipped Classroom: an Approach to Teaching and Learning. Education Journal, (July), P. 3

Hamdan, Noora. 2013. A Review Of Flipped Learning. (London: Pearson) P. 5

Jannette K. Klingner, Sharon Vaughn, Alison Boarman. 2007. Teaching Reading Comprehension to Students with Difficult Learning. (New York: The Guilford Press), P. 77

Knapp, Peter and Watkins, Megan. 2005. Genre, Text, Grammar: Technologies For Teaching And Assessing Writing. Sydney: University of New South Wales.

Karimi, Mehrnoosh and Hamzavi, Raouf. 2017. "The Effect of Flipped Model of Instruction on EFL Learners' Reading Comprehension: Learners' Attitudes in Focus". Jurnal Education, Vol. 8 No. 1, P. 1

McIntyre, Ellen, Hulan, Nancy, and Lane, Vicky. 2011. Reading Instruction for Diverse Classrooms: Research-Based, Culturally Responsive Practice. (New York: The Guilford Press,), P. 40Schumm, Jeanne Shay. 2006. 
English Education: Jurnal Tadris Bahasa Inggris pISSN 2086-6003 | eISSN 2580-1449

Vol. 14 (1), 2021 14-29

Reading assessment and Instruction for All Learners. (New York: The Guilford Press) P. 68

Tennett, Andrew, and Royle, Nicholas. 2004. An Indroduction to Literature,

Criticism and Theory (3rd Edition). (Britain: Pearson longman), P. 293 